\title{
Effect of Fetal or Adult Red Cells on Tissue Oxygenation and Myocardial Function in Normoxemic Newborn Lambs
}

\author{
J. C. FOURON, H. BARD, ${ }^{(22)}$ J. C. LE GUENNEC, AND M. R. VAN AMERIGEN \\ Perinatal and Cardiology Services and Centre de Recherche Pediatrique de l'Hopital Ste-Justine, Department of \\ Pediatrics, University of Montreal, Montreal, Quebec, Canada H3T IC5
}

\begin{abstract}
Summary
Twelve newborn lambs less than $48 \mathrm{hr}$ old had their high oxygen affinity blood exchanged for low-affinity fresh adult blood. Tissue oxygenation, hemodynamic status, blood gases, and myocardial function were compared before and after the exchange transfusion. The $P_{50}$ was increased from 18 to $29 \mathrm{~mm} \mathrm{Hg}$ after exchange transfusion; $\mathbf{p H}$ and hemoglobin levels remained constant; and there was no change in myocardial function, arteriovenous $\mathrm{O}_{2}$ content difference, $\mathrm{O}_{2}$ consumption, or cardiac output. However, mixed venous $\mathrm{Po}_{2}$ was significantly increased with low affinity red cells ( 33 versus $23 \mathrm{~mm} \mathrm{Hg}$ ).
\end{abstract}

\section{Speculation}

This study suggests that in the immediate neonatal period adequate a lowering of red cell oxygen affinity under normoxemic conditions can result in a increase in tissue $\mathbf{P o}_{2}$.

Early preterm newborn infants have blood with high oxygen affinity (2). Does this leftward displacement of the oxygen hemoglobin dissociation curve limit the delivery of oxygen to the tissues? Although improvement in tissue oxygenation has been suggested after exchange transfusion using adult blood $(6,8)$, the reason remains unclear. Most publications have compared various biologic parameters using adult red cells whose $\mathrm{O}_{2}$ affinity has been modified $(3,9,10,11,15,17,20)$. However, none of these studies would be directly related to the normal human preterm infant under normoxemic conditions. It was deemed important to evaluate, using an appropriate newborn animal model, whether the lowering of high oxygen affinity could have any advantage, as far as delivery of oxygen to the tissues was concerned, during the immediate neonatal period in normoxemic conditions.

The present study was undertaken to compare tissue oxygenation, hemodynamic status, blood gas changes, and myocardial performance of newborn lambs whose high oxygen affinity blood was exchanged for low oxygen affinity adult blood. The newborn lamb has during the first $48 \mathrm{hr}$ of life a $\mathrm{P}_{50}(18$ to $20 \mathrm{~mm} \mathrm{Hg})$ (1) which is similar to that of an early preterm newborn infant (2). The $P_{50}$ range of the adult sheep ( 35 to $40 \mathrm{~mm} \mathrm{Hg}$ ) is considerably higher (14).

\section{MATERIALS AND METHODS}

Twelve newborn lambs less than $48 \mathrm{hr}$ old were included in the study. The animals were prepared in conformance with the guiding principles in the care and use of animals as recommended by the Declaration of Helsinki. They were sedated enough to be kept asleep with repeated subcutaneous injections of Diazepam $(0.3$ $\mathrm{mg} / \mathrm{kg}$ every 20 to $30 \mathrm{~min}$ ). To eliminate sensibility to pain during catheter positioning, lidocaine hydrochloride (2\%) was used as a local anesthetic. To ensure comparable constant metabolic conditions, they all received an intravenous injection of curare $(0.3$ $\mathrm{mg} / \mathrm{kg}$ ). A quarter of this initial dose was then repeated every 30 $\mathrm{min}$. They were all mechanically ventilated with ambient air to maintain an arterial $\mathrm{PCO}_{2}$ of $35 \mathrm{~mm} \mathrm{Hg} \pm 5$. Temperature was kept constant at $38^{\circ} \mathrm{C} \pm 0.5$.

Polyethylene catheters were positioned in the right atrium and the descending aorta along with a Swan-Ganz 5F flow-dependent balloon catheter in the pulmonary artery using both of the femoral veins and one of the femoral arteries. Systemic and pulmonary artery pressures were recorded continuously on a Grass model 7 recorder. Two micromanometer tipped catheters (Millar, Mikrotip, No. 7-F, model PC-470; Millar Instruments, Houston, TX) were also placed, one from the carotid artery into the left ventricle (LV) and the other from the remaining femoral artery just above the aortic valve. Oxygen content was measured in samples taken from aorta and pulmonary artery using a Lex $\mathrm{O}_{2}$ con (Lexington Instrument Corporation, Waltham, MA). Throughout the study, the difference between the $\mathrm{O}_{2}$ content of the pulmonary artery and the right atrium was never greater than $2 \%$, indicating that there was no left-to-right shunt through the ductus arteriosus.

Samples obtained from descending aorta were used to determine $\mathrm{pH}, \mathrm{PaO}_{2}, \mathrm{PCO}_{2}, \mathrm{Hb}$ concentration, and oxygen saturation; oxygen saturations were also determined in right atrium and pulmonary artery. The mixed venous $\mathrm{PO}_{2}$ was determined on samples obtained from the pulmonary artery. All analysis were done using an IL Instrument Laboratory from Instrumentation Laboratory Inc. Lexington, MA (213 blood gas analyser tonometer, 208 gas mixing system, and 182 co-oximeter).

To measure oxygen consumption, expired air was collected, and minute-volume was measured in a spirometer. The $\mathrm{O}_{2}$ concentration in the expired air was determined with an $\mathrm{O}_{2}$ analyser apparatus S.3A (Applied Electrochemistry Inc., Sunnyvale CA). Cardiac output was calculated applying the Fick principle. The percentage of $\mathrm{O}_{2}$ tissue extraction was obtained according to the formula: arterial $\mathrm{O}_{2}$ content - venous $\mathrm{O}_{2}$ content/arterial $\mathrm{O}_{2}$ content $\times 100$. From the cardiac output and the mean pressures, it was possible to calculate the total resistance in the pulmonary and systemic circulations (12).

In five animals, throughout the experiment, the myocardial function data, which included the LV and aortic pressures obtained from the micromanometer tipped catheters, an electrocardiogram with a well identified $\mathrm{Q}$ wave, and an endocavity phonocardiogram obtained from the LV catheter, were all stored in a four-channel FM tape recorder (Hewlett-Packard, model 3960A, Palo Alto CA). The tape was later processed through an Electronics for Medicine recorder model DR 12, (Electronics for Medicine, White Plains, NY) allowing photographic recording of the tracings at a paper speed of $200 \mathrm{~mm} / \mathrm{sec}$. On the aortic pressure tracing, 
the pre-ejection period (PEP), isometric contraction time, and left ventricular ejection time (ET) were measured as well as the ratio $\mathrm{PEP} / \mathrm{ET}$ as described by Weissler et al. (18). The ratio PEP/ET and isometric contraction time are not influenced by change of heart rate and are well-known indices of myocardial function (18). The left ventricular pressure signal was processed through a precalibrated differentiator model $\mathrm{RC}-1$ giving a continuous assessment of the contractility of this cavity expressed as the $\mathrm{dp} / \mathrm{dt}$ in $\mathrm{mm} \mathrm{Hg} / \mathrm{sec}(13)$. The results of the systolic time intervals and the $\mathrm{dp} / \mathrm{dt}$ studies represent an average of five consecutive complexes.

After obtaining these data, all newborn animals had an exchange transfusion with freshly drawn maternal blood under sterile conditions. The blood was collected in $500 \mathrm{ml}$ blood sacs (Blood-Packs; Fenwal Laboratories, Deerfield IL). The amount used corresponded to approximately twice the blood volume (160 cc per $\mathrm{kg}$ ) of the newborn animal. After a recovery period of 30 min the same studies as previously described were repeated.

The $\mathbf{P}_{50}$ was determined by gas mixing tonometry pre- and postexchange transfusion and expressed in $\mathrm{mm} \mathrm{Hg}$ at a $\mathrm{pH} 7.4$, $\mathrm{PCO}_{2}$ of $40 \mathrm{~mm} \mathrm{Hg}$, and $37^{\circ} \mathrm{C}$. All data were expressed as a mean and S.D.

\section{RESULTS}

The hemoglobin affinity for oxygen expressed as the $\mathrm{P}_{50}$ increased from $18 \mathrm{~mm} \mathrm{Hg} \pm 3.1$ before to $29 \mathrm{~mm} \mathrm{Hg} \pm 2.8$ after the exchange transfusion (which indicated that approximately $80 \%$ of the fetal red cells had been exchanged). This increase is highly significant $(P<0.01)$. The following parameters were not modified pre- and postexchange transfusion: $\mathrm{pH}$ (pre, $7.44 \pm 0.06$; post, 7.45 \pm 0.06 ) and hemoglobin (pre, $12.2 \mathrm{~g} \% \mathrm{ml} \pm 1.8$; post, $11.9 \pm 1.2$ $\mathrm{g} \%$ ).

No significant change in arteriovenous oxygen content difference occurred despite the marked change in $\mathrm{P}_{50}$ (pre-exchange, $4.7 \mathrm{ml} / 100 \mathrm{ml} \pm 1.2$; postexchange, $4.9 \pm 1.0$ ). The percentage of $\mathrm{O}_{2}$ extraction was: pre-exchange, $31.8 \pm 8.2$, and postexchange, $37.7 \pm 6.7$. The cardiac output also remained stable being 265.4 $\mathrm{ml} / \mathrm{min} / \mathrm{kg} \pm 35.4$ before and $285.6 \mathrm{ml} / \mathrm{min} / \mathrm{kg} \pm 78.9$ after exchange; finally, the $\mathrm{O}_{2}$ consumption also stayed constant with an average value of $12.1 \mathrm{ml} / \mathrm{kg} \pm 2.2$ before exchange and 13.5 $\mathrm{ml} / \mathrm{kg} \pm 2.3$ after exchange. These findings are shown in Figure 1 .

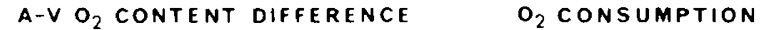

A-V $\mathrm{O}_{2}$ CONTENT DIFFERENCE

CARDIAC OUTPUT
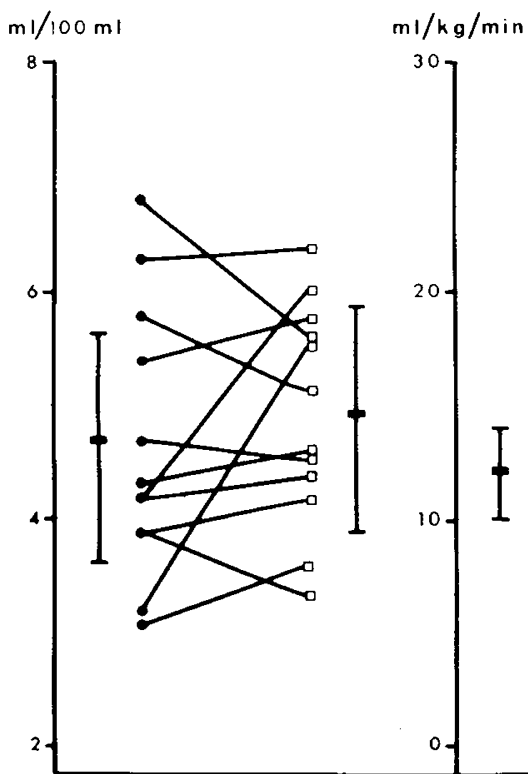

$\mathrm{ml} / \mathrm{kg} / \mathrm{min}$

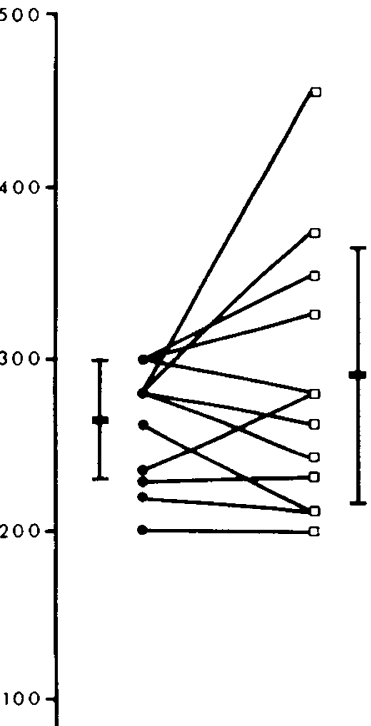

Figure 2 shows the arterial and mixed venous $\mathrm{Po}_{2}$ as well as the arterial and venous hemoglobin saturations before and after exchange transfusion. Mixed venous $\mathrm{PO}_{2}$ increased significantly in the presence of low-affinity adult red cells. The increase was from $23.8 \pm 5.2$ to $33.2 \pm 3.3 \mathrm{~mm} \mathrm{Hg}(P<0.01)$. There was no difference in the mean values obtained for arterial and venous hemoglobin saturations.

The myocardial function studies showed that heart rate, systolic time intervals, and $\mathrm{dp} / \mathrm{dt}$ of the left ventricle did not change during the study. The findings are illustrated on Table 1 . The mean systemic and pulmonary arterial pressures and resistances before and after exchange transfusion were similar; however, there were large variations in the resistances between individual animals. The values for the mean systemic and pulmonary arterial pressures in $\mathrm{mm} \mathrm{Hg}$ were $82 \pm 10$ versus $83 \pm 13$ and $32 \pm 6$ versus $32 \pm 6$, respectively. The mean values for the systemic and pulmonary arterial resistances in dynes $\cdot \mathrm{sec} \cdot \mathrm{cm}^{-5}$, were $5908 \pm$ 1523 versus $5703 \pm 1539$ and $2344 \pm 664$ versus $2170 \pm 602$, respectively.

\section{DISCUSSION}

The transport of oxygen from the lungs to the tissues is influenced by the pulmonary gas exchange, the blood-carrying capacity, the cardiac output, and the hemoglobin oxygen affinity (7). In this series of experiments, an attempt was made to isolate oxygenhemoglobin affinity as a variable and to elucidate its influence on tissue oxygen delivery and myocardial function. This was achieved successfully by maintaining a stable and constant metabolic activity as well as $\mathrm{O}_{2}$ consumption by sedating, curarizing, and mechanically ventilating the newborn lambs. The $\mathrm{O}_{2}$ consumption of the animal used in this study as well as the cardiac output was in the same range as has been reported by others using anesthetized newborn lambs $(4,5,19)$. The experiments were always carried out at less then $48 \mathrm{hr}$ of age because oxygen consumption (5) and $P_{50}$ (2) can change dramatically in newborn lambs during the first wk of life.

Despite the marked change in $P_{50}$ obtained by the exchange transfusion, the $\mathrm{O}_{2}$ delivered to the tissues remained unaltered. However, a significant increase in the arteriovenous oxygen tension differences was found when fetal red cells were in circulation. This was due to a more substantial decrease in the mixed venous
O, EXTRACTION

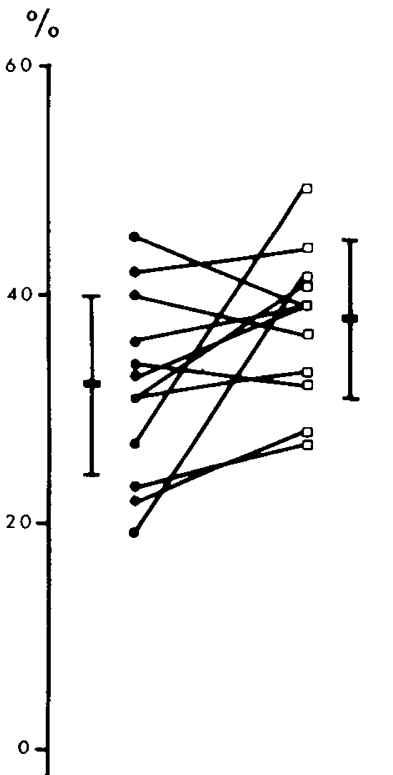

Fig. 1. Arteriovenous $\mathrm{O}_{2}$ content differences, $\mathrm{O}_{2}$ consumption, cardiac output, and $\mathrm{O}_{2}$ extraction in 12 newborn lambs with high-affinity red cells and low-affinity cells ( $\square$ ). The values for individual animals are connected by lines. Bars and vertical line, mean \pm S.D. 


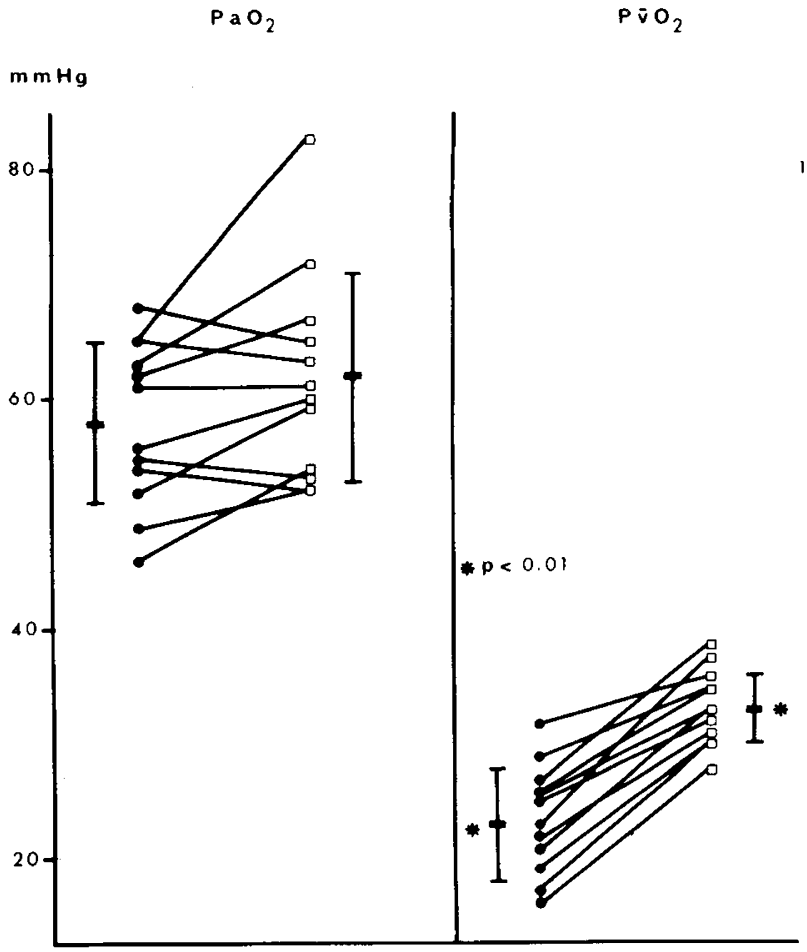

Fig. 2. Arterial and venous $\mathrm{Po}_{2}$ and hemoglobin saturations in 12 newborn lambs with high-affinity red cells $(\square)$ and low-affinity red cells

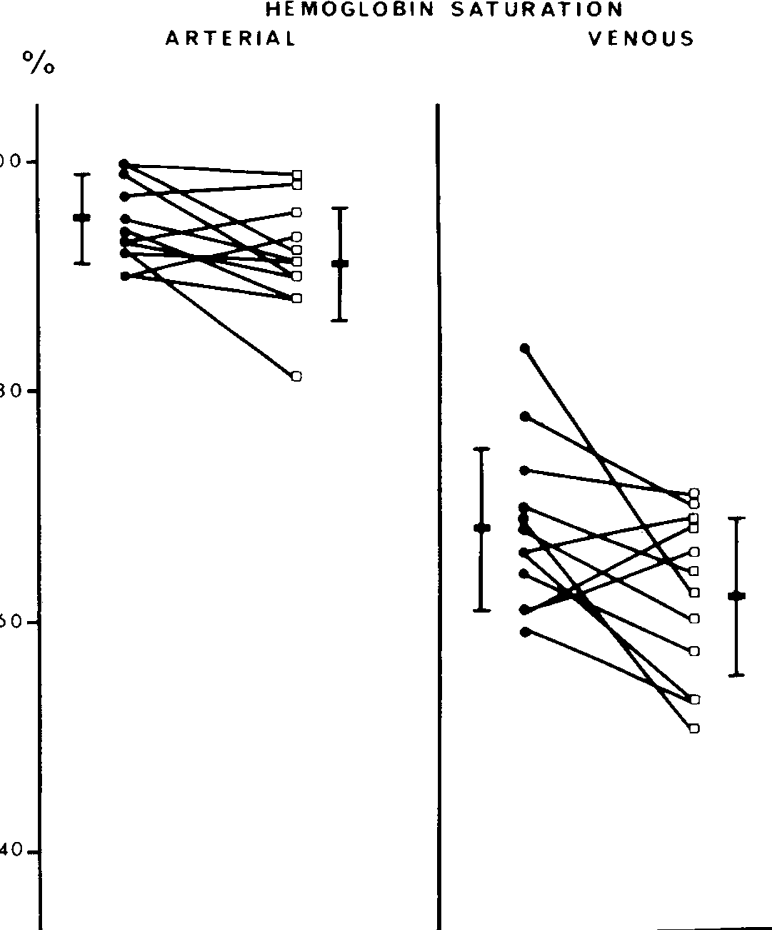

. The values for individual animals are connected by lines. Bars and vertical line, mean \pm S.D.

Table 1. Heart rate (in beats/min), systolic time intervals (in $\mathrm{msec}$ ) and $\mathrm{dp} / \mathrm{dt}$ (in $\mathrm{mm} \mathrm{Hg} / \mathrm{sec}$ ) of the left ventricle of newborn lambs with fetal and adult red cells

\begin{tabular}{ccccccc}
\hline & Heart rate & PEP & ET & PEP/ET & ICT $^{1}$ & dp/dt \\
\hline Fetal & $244 \pm 29$ & $39 \pm 7$ & $120 \pm 11$ & $0.32 \pm 0.03$ & $15 \pm 5$ & $4075 \pm 1616$ \\
Adult & $242 \pm 26$ & $37 \pm 3$ & $118 \pm 9$ & $0.31 \pm 0.02$ & $14 \pm 6$ & $3998 \pm 1016$ \\
\hline
\end{tabular}

${ }^{1} \mathrm{ICT}$, isometric contraction time.

$\mathrm{Po}_{2}$ in the high $\mathrm{O}_{2}$ affinity group. The level of mixed venous blood tension is considered a reliable index of peripheral capillary and tissue oxygen tension (16). The rate of transfer of oxygen from the blood to the tissues depends mainly upon the pressure gradient between the two components, therefore, a lowering of mixed venous $\mathrm{PO}_{2}$ without evidence of decreased $\mathrm{O}_{2}$ consumption indicated that the mixed venous oxygen tension compensated for the high $\mathrm{O}_{2}$ affinity of the fetal red cells, and adequate $\mathrm{O}_{2}$ was available for tissue requirements under normoxic conditions.

Some investigators in animal studies have suggested that variations in blood oxygen affinity results in changes in both venous $\mathrm{PO}_{2}$ as well as cardiac output so that $\mathrm{O}_{2}$ consumption remains stable (11). These authors postulated that a left-sided shift in the oxygen-hemoglobin dissociation curve could result in a falling venous $\mathrm{PO}_{2}$ or and an increase in cardiac output. In the present study, only mixed venous $\mathrm{PO}_{2}$ changed. Myocardial function as well as cardiac output and arteriovenous $\mathrm{O}_{2}$ content differences remained constant, irrespective of the type of red cells in the circulation.

The findings in our study could reflect the consequences of a rapid decrease of red cell oxygen affinity during the immediate neonatal period, and they suggest that the position of the oxygenhemoglobin dissociation curve has little or no significance in the newborn lamb under stable metabolic conditions with a normal arterial oxygenation. However, the exchange of high-affinity blood for low-affinity blood causes an increase in mixed venous $\mathrm{PO}_{2}$ (Fig. 3). Although one cannot extrapolate the results of these experiments directly to the human newborn infant, the relationship between venous $\mathrm{PO}_{2}$ and mean tissue $\mathrm{PO}_{2}$ is considered a good approximation under stable conditions (16). A decrease in red blood cell oxygen affinity could result in an increase in mean tissue $\mathrm{PO}_{2}$ during the neonatal period.
Effect of leftward shift of the ODC

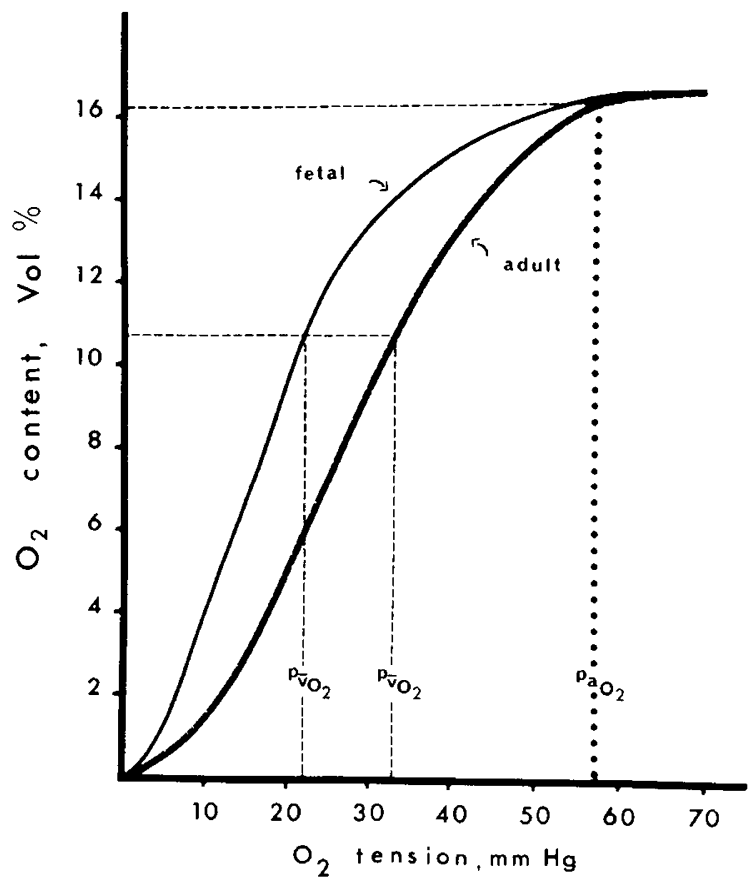

Fig. 3. The effect of the shift of the oxygen-hemoglobin dissociation curve on oxygen transport. The fetal curve lowers $\mathrm{P}_{\bar{v}} \mathrm{O}_{2}$ and does not limit the transfer of oxygen. 


\section{REFERENCES AND NOTES}

I. Bard, H. Fouron, J. C., Grothe, A. M., Soukini, M. A., and Cornet, A.: The adaptation of the fetal red cells of newborn lambs to extrauterine life. Pediatr. Res., 10: 823( 1976).

2. Bard, H., and Teasdale, F.: Red cell oxygen affinity, hemoglobin type, 2,3diphosphoglycerate and $\mathrm{pH}$ as a function of fetal development. Pediatrics, 64: 483 1979).

3. Bowen, J. C., and Fleming, W. H.: Increased oxyhemoglobin affinity after transfusion of stored blood. Evidence for circulatory compensation. Ann. Surg., 180: 760 (1974).

4. Cross, K. W., Dawes, G. S., and Mott, J. C.: Anoxia, oxygen consumption and cardiac output in newborn lambs and adult sheep. J. Physiol. (Lond), 146: 316 (1959).

5. Dawes, G. S., and Mott, J. C.: The increase in oxygen consumption of the lambs after birth. J. Physiol. (Lond.), 146: 295 (1959).

6. Delivoria-Papadopoulos, M., Miller, L. D., Foster, R. E., II, and Oski, F. A.: The role of exchange transfusion in the management of low-birth-weight infants with and without severe respiratory distress syndrome. I. Initial observations. J. Pediatr., 89: 273 (1976).

7. Finch. C. A., and Lenfant, C.: Oxygen transport in man. N. Engl. J. Med., 286: 407 (1972).

8. Gottuso, M. A., Williams, M. L., and Oski, F. A.: The role of exchange transfusions in the management of low-birth-weight infants with and without severe respiratory distress syndrome. II. Further observations and studies of mechanisms of action. J. Pediatr., 89: 279 (1976)

9. Guy, J. T., Bromberg, P. A., Metz, E. N., Ringle, R., and Balcerzak, S. P.: Oxygen delivery following transfusion of stored blood. I. Normal rats. J. Appl. Physiol., 37: 60 (1974).

10. Harken, A. H., and Woods, M.: The influence of oxyhemoglobin affinity on tissue oxygen consumption. Ann. Surg., 183: 130 (1976).

11. Krall, M. A., Bristow, J. D., Welch, J. E., and Metcalfe, J.: Physiologic effects of lowered blood oxygen affinity in dogs. Respir. Physiol., 33: 263 (1978).
12. Krovetz, L. J., and Goldbloom, S.: Normal standards for cardiovascular data: I. Examination of the validity of cardiac index. Johns Hopkins Med. J., 130: 174 (1972).

13. Mason, D. T.: Usefulness and limitations of the rate of rise of intraventricular pressure $(\mathrm{dp} / \mathrm{dt})$ in the evaluation of myocardial contractility in man. Am. $\mathbf{J}$. Cardiol., 23: 516 (1969).

14. Naughton, M. A., Meschia, G., Battaglia, F. C., Hellegers, A., Hagopian, H., and Barron, D. H.: Hemoglobin characteristics and the oxygen affinity of the bloods of dorset sheep. Q. J. Exp. Physiol. Cogn. Med. Sci., 48: 313 (1963)

15. Riggs, T. E., Shafer, A. W., and Guenter, C. A.: Acute changes in oxyhemoglobin affinity: effects on oxygen transport and utilization. J. Clin. Invest., S2: 2660 (1973)

16. Tenney, S. M.: A theoretical analysis of the relationship between venous blood and mean tissue oxygen pressures. Respir. Physiol., 20: 283 (1974).

17. Valeri, C. R., and Collins, F. B.: Physiologic effects of 2,3-DPG-depleted red cells with high affinity for oxygen. J. Appl. Physiol., 31: 823 (1971).

18. Weissler, A., Lewis, R., and Leighton, R.: The systolic time intervals as a measure of left ventricular performance in man. Progress in Cardiology pp. 155-183 (Lea \& Febiger, Philadelphia, 1972).

19. Woods, J. R., Jr., Dandavino, A., Brinkman, C. R., III, Nuwayhid, B., and Assali, N. S.: Cardiac output changes during neonatal growth. Am. J. Physiol., 3: H520 (1978)

20. Woodson, R. D., Wranne, B., and Detter, J. C.: Effects of increased blood oxygen affinity on work performance of rats. J. Clin. Invest., 52: 2717 (1973).

21. The authors are grateful for the technical assiatance provided by Janie Prosmanne, B.Sc. and Marie-Thérèse Rabeau, B.Sc. They are also very thankful for the cooperation of Sylvie Tassé in typing the manuscript.

22. Requests for reprints should be addressed to: Harry Bard, Department of Pediatrics, Hôpital Sainte-Justine, 3175 Chemin Sainte-Catherine, Montreal, Quebec, Canada H3T 1C5

23. This research was supported by Grant MA-5120 from the Medical Research Council of Canada and in part by The Canadian Heart Foundation.

24. Received for publication August 13, 1980 .

25. Accepted for publication November 6, 1980. 